\title{
Impact of Economic Globalization on Life Expectancy in Nigeria
}

\section{Popoola Oladayo Timothy*}

Department of Economics, Ahmadu Bello University, Zaria, Nigeria

\begin{abstract}
In recent years, there are been different opinions about the effects of economic globalization on longevity of citizens in developing countries. While some scholars evidenced that economic globalization has increase major health hazards and transmission of infectious diseases; others revealed that its improves life expectancy through education and access to modern health technology. Therefore, this study empirically examined the effects of globalization on life expectancy in Nigeria between the periods of 1986 to 2016 . The research employed Augmented Dickey-Fuller (ADF) to test for the unit root of the variables, and Johanson Co-integration test to investigate the long-run relationship among the variables. The findings of this study indicates that economic globalization have positive and significant impact on life expectancy in Nigeria. Hence, in providing policies that concern globalization in Nigeria, economic-dimension of globalization should be enhanced for it has long-run relationship with enhancement of longevity in Nigeria.
\end{abstract}

Keywords: Economic Globalization; Life expectancy; Co-integration analysis; Nigeria

\section{JEL Code: F6, I15, C13}

\section{Introduction}

Over the last three decades, economic globalization (which is often characterized by international trade and finance) has been the key driving force behind the overall process of globalization in both developed and developing nations [1]. This dimension include trade in goods and services, regulations, taxes and tariff on trades, foreign direct and portfolio investments, international debt and reserves, investment restrictions and openness [2,3]. Other dimensions of globalization are social and political dimensions. The social dimension involves the freedom to visit other countries, access to internet and television, press freedom and international airports [4]; while the political dimension relates to embassies, United Nations peace keeping missions, international treaties and organizations [5].

Although there are growing studies on the importance of economic dimension of globalization in developing countries in recent years [6-9]. However, there is no consensus about the effects of economic dimension of globalization on health status of citizens in developing countries. For instance, some scholars evidenced that economic globalization has increase major health hazards and transmission of infectious diseases through marketing of unhealthy products and lifestyles, fake drugs, and migration of quality health professionals $[1,10,11]$. While others revealed that its improves health indicators through education, health tourism, and access to modern health technology [11-14]. This implies that there is mixed findings about the impact of economic globalization on health indicators in developing nations.

Nigeria is a developing country facing the problem of low life expectancy. Notably, the average life expectancy at birth in Nigeria is merely 53 years in recent years, while it is above 80 years for countries like France, Japan, Singapore, and Hong Kong. For Ghana and Niger, their average life expectancies were 64 and 61 years respectively in 2015 [2]. Thus, this study empirically examined the impact of economic globalization on life expectancy in Nigeria by providing answers to the following research questions: does economic globalization factors matter in predicting life expectancy in Nigeria? Is there any longrun relationship between economic-dimension of globalization and life expectancy in Nigeria? These findings are paramount to healthy contribution in respective literature as they will help policymakers to set policy targets for enhancing healthy outcomes in Nigeria. The outline of the paper was as follows: literatures were reviewed in section two for more insight. Section three presented methods, econometrics specification and data source, four described the analysis data, presented and interpret the findings. Then section five concludes the study with policy recommendations.

\section{Literature Reviews}

Conceptually, globalization refer to the easy circulation of information and technology, trade, capital, people, products, and services. It is also an extension of liberal economy that expand global awareness of the planetary perspective and enlarges sense of time and space [15]. This implies that globalization increases the sense of community within the global environment through fundamental restructuring and reorganization of the world economy, policy and environment in a complex context [16]. In this respect, Lam [17] observed that, globalization has become an ideological discourse that drives change and perception in term of need to respond to a new world order. According to KOF World Globalization Index by Swiss Economic Institute [18], there are three dimensions of globalizationeconomic, social, and political globalizations.

On the other hand, there are various indicators of health status. These include mortalities, morbidity, diseases burden statistics, and average life expectancy. The average life expectancy (at birth) refers to the number of years a newborn is expected to live if mortality patterns at the time of birth remains constant in the future [19]. It is the averageperiod that a person is expected to live as determined taking account of current economic situation. This also reflects the overall mortality level of a population, and summarizes the mortality pattern that prevails across all age groups [19]. It also indicates the number of years a newborn infant would live if patterns of mortality prevailing for all people at the time of birth were to stay the same throughout his life. Hence, it is an important index of long life and quality of living [20].

${ }^{*}$ Corresponding author: Popoola Oladayo Timothy, Department of Economics, Ahmadu Bello University, Zaria, Nigeria, E-mail: poladayo@gmail.com

Received April 30, 2018; Accepted May 14, 2018; Published May 21, 2018

Citation: Timothy PO (2018) Impact of Economic Globalization on Life Expectancy in Nigeria. Health Econ Outcome Res Open Access 4: 152. doi: 10.4172/2471-268x/1000152

Copyright: (c) 2018 Timothy PO. This is an open-access article distributed under the terms of the Creative Commons Attribution License, which permits unrestricted use, distribution, and reproduction in any medium, provided the original author and source are credited. 
Table 1 reveals average life expectancy at birth of Cote d'Ivoire, Ghana, South Africa, Rwanda, and Nigeria. The average life expectancy at birth (total) in Nigeria increased marginally from 46 years in 1995 to about 53 years in 2015, while Rwanda's life expectancy increased from 31 years to about 65 years during the same period [2]. In comparison, average life expectancy at birth in Nigeria is lower compared with Ghana and South Africa.

There are several literatures that concern the theories and empirical relationship between economic globalization and health indicators. Theoretically, Grossman [21] observe the macroeconomic factors responsible for health indicators (living standard and life expectancy), while Roger [22] presents the conceptual frameworks on how income impact health indicators. In recent years, Woodward et al. [1] examines the conceptual framework to present the direct and indirect effects of globalization on health through the national economy, household economies, and health-related sectors such as, water, sanitation and education. Empirically, while some authors $[12,13,16,23]$ find that increasing economic globalization may improve health indicators, others $[1,16,17]$ conclude to the opposite. Owen and $\mathrm{Wu}[23]$ examine the relationship between globalization and mortality rate considering the period of 1960 to 1995 for 219 developed and developing countries. They found that globalization has inverse impact of infant mortality rate but positively related to life expectancy.

The findings of Owen and $\mathrm{Wu}$ [23] seem to suggest that the relationships between globalization and health indicators depend on the level of development of a country and whether the country is developing or not. Bussmann [24] investigated the effect of economic integration on female life expectancy in developing countries. He obtained that female life expectancy is not effected by globalization in the case of developing countries. Nilsson and Bergh [12] further analyze the relationship between globalization and life expectancy with a panel of 92 developing countries for the period of 1970 to 2005 . This study also obtained strong positive effect of economic globalization on life expectancy.

Rafat et al. investigates the relationship between economic, social and political globalization and health in developing countries using KOF indicators. Their findings indicate that economic globalization has a negative effect on life expectancy in developing countries [23]. Recently, Ali and Audi [16] investigated the impact of globalization on life expectancy in Pakistan. The study uses time series data for the period 1980 to 2015. Their results of Autoregressive Distributed Lag (ADL) and Granger Causality indicate that globalization have positive and significant impact on life expectancy in Pakistan.

It is thought of interest to examine the case of a developing country like Nigeria which economic success has been based on international trade of oil and agricultural raw material. Unlike the methodology used in precious studies, the aim of this study is to investigate the longrun relationships between economic globalization and life expectancy by using an econometric time series analysis which relies on an Autoregressive Distributed Lag (ADL).

\section{Methodology}

\section{Theoretical framework}

The theoretical framework for the study was based on Grossman [21] that emphasized that health indicators (including life expectancy) are often affected by various factors. These factors in addition to economic globalization include education, diet, and healthy lifestyle. As Berkman et al. [25] put it, citizens allocate their resources to produce healthy living, and this average life expectancy are often influenced by economic globalization. This implies that:

$$
\mathrm{LE}_{\mathrm{t}}=\mathrm{f}\left(\mathrm{EG}_{\mathrm{t}}\right)
$$

Where $L_{t}$ is the average life expectancy (at birth) and $E_{t}$ represent the economic globalization.

\section{Model specification}

Following the methodology as employed by Ali and Audi [16], the model of the study from equation (1) is as follow:

$$
\mathrm{LE}_{\mathrm{t}}=\mathrm{f}\left(\mathrm{T}_{\mathrm{t}}, \mathrm{FDI}_{\mathrm{t}}, \mathrm{CO}_{2 \mathrm{t}}\right)
$$

Where $\mathrm{LE}_{\mathrm{t}}$ is the average life expectancy at birth; $\mathrm{T}$ is trade, FDI represent the foreign direct investment; $\mathrm{E}$ denotes education, and $\mathrm{CO}_{2}$ represent the environmental degradation. However, this study differs from Ali and Audi [16] in the sense that, this study account for the trade (T), and foreign direct investment (FDI) which Ali and Audi [16] ignored. These variables $\mathrm{T}, \mathrm{FDI}$, and $\mathrm{CO}_{2}$ are appropriate proxy for economic globalization (EG) and international trade and finances [2]. The model from the functional specification in equation (2) can be written in the following econometrics form:

$$
\mathrm{LE}_{\mathrm{t}}=\alpha+\beta 1 \mathrm{~T}_{\mathrm{t}}+\beta_{2} \mathrm{FDI}_{\mathrm{t}}+\beta 3 \mathrm{CO}_{2 \mathrm{t}}+\boldsymbol{\mu}
$$

where $t$ is the time period from 1986 to 2015 , and $\boldsymbol{\mu}$ is the error term

\section{Unit root and co-integration}

For time series variables, it is expected that these variables are stationary (having constant mean and variance) over time. Thus, the preliminary empirical step of the methodology is the degree of integration of each variable using Augmented Dickey-Fuller (ADF) proposed by Dickey and Fuller $[26,27]$ unit root procedure using the following equation:

$$
\Delta \mathrm{LE}_{\mathrm{t}}=\alpha+\beta \mathrm{t} \mathrm{LE}_{\mathrm{t}-1}+\sum \delta \mathrm{j} \Delta \mathrm{LE}_{\mathrm{t}-\mathrm{j}}+\varepsilon_{\mathrm{t}}
$$

Where $L_{t}$ is the level of the variable under consideration, with lag length so the residuals $\varepsilon_{t}$ can be white noise. Before analyzing the Autoregressive Distributed Lag (ADL) it is necessary to determine the order of the long-run relationships among the variables of the system; thus, the study test for the multivariate co-integration by employing Johansen and Johansen and Juselius's [28] technique computing maximal Eigenvalue and Trace statistics.

\section{Variables and sources}

The average life expectancy at birth (LET) in Nigeria is the dependent variables. Trade Openness (TO), and Foreign Direct Investment (FDI) are the independent variables as proxy for economic globalization, while carbon dioxide $\left(\mathrm{CO}_{2}\right)$ is the control variable. The Table 2 depicts the variables, measurement and sources. The data used was for the period of 1986-2015 and were sourced from World Bank Development Indicators [2].

\section{Empirical Results}

\section{Descriptive statistics}

The study proceeds with a descriptive analysis of the variables employed in the estimation in order to diagnose and better understand the characteristics of the time series data used in estimations. The descriptive statistics of variables for the study is presented in Table 3. From the table, the average LE is 48 years old with standard deviation of 2.47 years. 
Citation: Timothy PO (2018) Impact of Economic Globalization on Life Expectancy in Nigeria. Health Econ Outcome Res Open Access 4: 152. doi: $10.4172 / 2471-268 x / 1000152$

Page 3 of 4

In addition, the correlation matrix analysis is carried out in order to ascertain the extent of the relationship amongst the variables and also to check for the existence of multi-collinearity amongst the explanatory variables. The correlation matrix table presented in Table 4 reveal that, high direct correlation exists between le and trade $(\mathrm{T})$ and foreign direct investment (FDI) respectively.

\section{Unit root test}

The study tests for unit roots for all the variables - LE, T, FDI, and $\mathrm{CO}_{2}$. Augmented Dickey-Fuller (ADF) are used to perform the tests. The results of the stationarity tests of variables at level are presented in Table 5. The stationarity of the time series data is necessary for examining the co-integration relationship among the variables of the model, as most of the time series data has unit root problem which makes regression results spurious. The study use ADF unit root test for solving the unit root problem. The estimated results of the unit root are presented in Table 4 . The findings show that life expectancy (LE), trade openness (TO), foreign direct investment (FDI), and carbon dioxide emission (CO2) are not stationary at level so the study cannot reject null hypothesis of non-stationary for all variables. Therefore, the order of integration is I (1) for all the variables which allowed the study to applying Johanson approach of co-integration.

\section{Johnason Co-integration test}

There are numbers of co-integration tests available [29]. However, given the unit root properties of the study, this study employed Johnasen test to establish whether or not there is a long-run co-integrating relationship among the variables. The findings as depicted in Tables 6 and 7 revealed that both the Trace and Maximal Eigenvalue statistics indicate the existence of one co-integrating relationships between the variables at 1 per cent level. Therefore, the study concludes that there exist long-run relationship between life expectancy and economic globalization variables (trade openness, foreign direct investment) in Nigeria.

\section{Conclusion and Policy Recommendation}

The study empirically examined the long-run relationship between life expectancy and economic globalization in Nigeria covering the period of 1986 to 2015. The research employed Augmented Dickey-Fuller (ADF) to test for the unit root of the variables, and Johanson Co-integration test to investigate the longrun relationship among the variables. The findings of this study indicates that economic globalization have positive and significant impact on life expectancy in Nigeria. Hence, in providing policies that concern globalization in Nigeria, economic-dimension of globalization that relates to trade openness and foreign direct investment should be encouraged to improve the longevity in Nigeria. However, carbon dioxide emission should be reduced as it could affect the long-run relationship of longevity and economic globalization in Nigeria.

\begin{tabular}{|c|c|c|c|c|c|c|c|c|c|c|}
\hline & & 1975 & 1980 & 1985 & 1990 & 1995 & 2000 & 2005 & 2010 & 2015 \\
\hline $\begin{array}{l}\text { Cote d'Ivoire } \\
\text { Ghana } \\
\text { South Africa } \\
\text { Rwanda } \\
\text { Nigeria }\end{array}$ & 44.9 & $\begin{array}{l}47.7 \\
50.8 \\
54.2 \\
47.9 \\
43.4\end{array}$ & $\begin{array}{l}50.7 \\
52.3 \\
56.9 \\
50.4 \\
45.5\end{array}$ & $\begin{array}{l}52.6 \\
54.1 \\
59.9 \\
33.4 \\
46.3\end{array}$ & $\begin{array}{l}52.6 \\
56.7 \\
62.1 \\
31.6 \\
46.1\end{array}$ & $\begin{array}{l}49.5 \\
57.5 \\
61.4 \\
48.1 \\
46.1\end{array}$ & $\begin{array}{l}46.7 \\
56.9 \\
55.8 \\
54.7 \\
46.6\end{array}$ & $\begin{array}{l}47.7 \\
58.7 \\
51.5 \\
61.4 \\
48.6\end{array}$ & $\begin{array}{l}50.1 \\
60.6 \\
54.4 \\
64.5 \\
51.3\end{array}$ & $\begin{array}{l}51.9 \\
61.4 \\
57.4 \\
\\
53.0\end{array}$ \\
\hline
\end{tabular}

Source: Compiled from World Development Indicator, 2017

Table 1: Average Life Expectancy at birth (total) in Nigeria compare to other countries.

\begin{tabular}{|c|c|c|}
\hline Variable & Description/Measurement & Source \\
\hline LE & Life Expectancy at birth, total (years) & WDI (2017) \\
\hline TO & Aggregate exports and imports as a ratio of GDP & WDI (2017) \\
\hline FDI & Foreign Direct Investment (N'billion) & WDI (2017) \\
\hline $\mathrm{CO}_{2}$ & Carbon dioxide emission metric tons per capita \\
\hline
\end{tabular}

Note: WDI means World Bank Development Indicators

Source: Author Compilation, 2018

Table 2: Data Description and Sources.

\begin{tabular}{|c|c|c|c|}
\hline Variable & LE & T & FDI \\
\hline Mean & 48.18 & $7,811,900,000$ & $3,030,000,000$ \\
\hline Standard Deviation & 2.47 & $9,049,090,000$ & $2,690,000,000$ \\
\hline Minimum & 46.07 & $14,900,000$ & $193,000,000$ \\
\hline Maximum & 53.05 & $26,232,500,000$ & $3,2759.27$ \\
\hline Observation & 30 & 30 & $104,689.63$ \\
\hline
\end{tabular}

Source: Own Computations with Stata 13

Table 3: Descriptive Statistics of Variables in Nigeria.

\begin{tabular}{|c|c|c|c|}
\hline & LE & T & FDI \\
\hline LE & 1.0000 & & \\
\hline T & 0.9786 & 1.0000 & \\
\hline FDI & 0.8289 & 0.8558 & 1.0000 \\
\hline CO $_{2}$ & 0.7268 & 0.6955 & 0.6231 \\
\hline
\end{tabular}

Source: Own Computations with Stata 13

Table 4: Correlation Matrix (1981-2016). 
Citation: Timothy PO (2018) Impact of Economic Globalization on Life Expectancy in Nigeria. Health Econ Outcome Res Open Access 4: 152. doi: $10.4172 / 2471-268 x / 1000152$

Page 4 of 4

\begin{tabular}{|c|c|c|c|}
\hline Variables & ADF test at level & $\mathbf{1 0 \%}$ Critical level & Order of Integration \\
\hline LE & -7.282 & -3.233 & I(1) \\
\hline TO & -3.467 & -3.233 & I(1) \\
\hline FDI & -3.253 & -3.233 \\
\hline $\mathrm{CO}_{2}$ & -4.175 & -3.233 \\
\hline
\end{tabular}

Source: Own Computations with Stata 13

Table 5: Results of Unit Root Tests (1986-2015).

\begin{tabular}{|c|c|c|c|}
\hline Hypothesized & Eigenvalue & Trace Statistic & Prob. \\
\hline None $^{*}$ & 0.9494 & 126.21 & $0.0000^{* * *}$ \\
\hline At most 1* & 0.6548 & 42.65 & 47.87 \\
\hline At most 2 & 0.3081 & 12.88 & 29.80 \\
\hline
\end{tabular}

Source: Author Compilation, 2018

Table 6: Johnason Unrestricted Co-Integration Rank Test (Trace).

\begin{tabular}{|c|c|c|c|}
\hline Hypothesized & Eigenvalue & Trace Statistic & Prob. \\
\hline None $^{*}$ & 0.9494 & 83.55 & $0.0000^{\star * *}$ \\
\hline At most 1* & 0.6548 & 29.78 & 27.58 \\
\hline At most 2 & 0.3081 & 10.31 & $0.0010^{\star * *}$ \\
\hline
\end{tabular}

Source: Author Compilation, 2018

Table 7: Johnasen Unrestricted Co-Integration Rank Test (Maximum Eigenvalue).

\section{References}

1. Woodward D, Drager N, Beaglehole R, Lipson R (2001) Globalization and Health: A Framework for Analysis and Action. Bulletin of the World Health Org 79: 875-881

2. World Bank (2017) World Development Indicators. World Bank.

3. Gwartney J, Hall JC, Lawson R (2017) 2017 Economic Freedom Dataset.

4. International Telecommunications Union (2017) World Telecommunication and ICT Indicators Database.

5. United Nations Conference on Trade and Development (2017) Investment Policy Hub.

6. Imani-Rad M, Mirzaei V (2010) Review Globalization Indicators. Management Compass Magazine. 199: 27-23.

7. Rafat B, Emadzadeh M, Ahmadi K (2013) Economic, Social and Political Aspect of Globalization on Health in Developing Countries. Intern J Academic Res Business Soc Sci 3: 384-402.

8. Jahan S, Wang D (2016) Capital Account Openness in Low-Income Developing Countries: Evidence from a New Database. IMF Washington.

9. IMF (2017) International Investment Position. International Monetary Fund.

10. Labonte R, Schrecker T (2007) Toward Health-Equitable Globalization: Rights, Regulation and Redistribution? Rev Intern Econom 13: 312-335.

11. Ajayi AD, Garba SN (2008) Role of Information and Communication Technologies in Health Care Delivery in Nigeria. A paper presented as the Annual Conference of Kaduna State Nurses Organized by the State Ministry of health, Kaduna. pp: 22-24.

12. Nilsson T, Bergh A (2012) Income Inequality and Individual Health: Exploring the Association in a Developing Country. IFN pp: 89.

13. Martens P, Akin S, Huynen M, Raza M (2010) Is Globalization Healthy: A Statistical Indicator Analysis of the Impacts of Globalization on Health. Globalization and Health 6: 371- 389.

14. Inmpey JC (2012) An Empirical Analysis of the Impact of Globalization on Health in Nigeria: Evidence from Enugu State. An MSc Economics Dissertation, University of Nigeria, Nigeria.

15. Koc A, Ata AY, Cirkin Z (2013) Empirical Investigation on Globalization and
Social Polarization: Cross Country Analysis. Intern J Econom Financial Issues 3: 206-213.

16. Ali A, Audi M (2016) The Impact of Income Inequality, Environmental Degradation and Globalization on Life Expectancy in Pakistan: An Empirical Analysis. MPRA 71112.

17. Lam YY (2010) Impact of Globalization on Higher Education: An Empirical Study of Education Policy and Planning of Design Education in Hong Kong Intern Edu Studies 3: 73-85.

18. Gygli SF, Sturm H (2018) The KOF Globalization Index-Revisited, KOF Working. pp: 439.

19. World Health Organization (2006) Working Together for Health. The World Health Report.

20. Grepin KA, Bharadwaj P (2015) Maternal Education and Child Mortality in Zimbabwe. J Health Econom 44: 97-117.

21. Grossman M (1972) On the Concept of health Capital and the Demand for Health. J Political Econom 80: 223-255.

22. Roger GB (1979) Income and Inequality as Determinants of Mortality: An International Cross-Section Analysis. Population Studies 33: 343-351.

23. Owen AL, Wu S (2007) Is Trade Good for your Health? Rev Intern Econom 15: $660-682$

24. Bussmann M (2009) The Effect of trade Openness on Women's Welfare and Work life. World Developt 37: 1027-1038.

25. Berkman LF, Glass T, Brissette I, Seeman TE (2000) From Social Integration to Health: Durkheim in the New Millennium. Soc Sci Med 51: 843-857.

26. Dickey D, Fuller W (1979) Distribution of the Estimators for Autoregressive Time Series with a Unit Root. J American Statistical Association74: 427-431.

27. Dickey D, Fuller W (1981) Likelihood Ratio Statistics for Autoregressive Time Series with a Unit Root. Econometrica 49: 1057-1072.

28. Johansen S, Juselius K (1990) Maximum Likelihood Estimation and Inference on Co-integration with Applications to the Demand for Money. Oxford Bulletin Econom Stat 52: 169-210.

29. Johansen S (1991) Estimation and Hypothesis Testing of Co-integration Vectors in Gaussian Vector Autoregressive models. Econometrica 59: 1551 1580. 